\title{
Litiasis vesical sintomática
}

\author{
Caballero JP, Giner C, Leivar, Galiano JF. \\ Servicio de Urología. Hospital General Universitario de Alicante.
}

Actas Urol Esp. 2006;30(8):847

$\mathrm{N}$ uestro paciente tiene 60 años y como únicos antecedentes cólicos renoureterales de repetición y litiasis vesical de ácido úrico intervenida mediante litectomía abierta hace 15 años. Desde hace 3 semanas presenta dolor hipogástrico moderado, tenesmo y hematuria macroscópica. Se le realiza una urografía intravenosa en la que se observa, en la vejiga, un defecto de repleción circular de unos 5 centímetros. Se le realizó un examen cistoscópico observándose únicamente una litiasis vesical. Se decidió realizar de nuevo una litectomía vesical abierta. Cuando se extrajo la litiasis nos llamó mucho la atención la forma

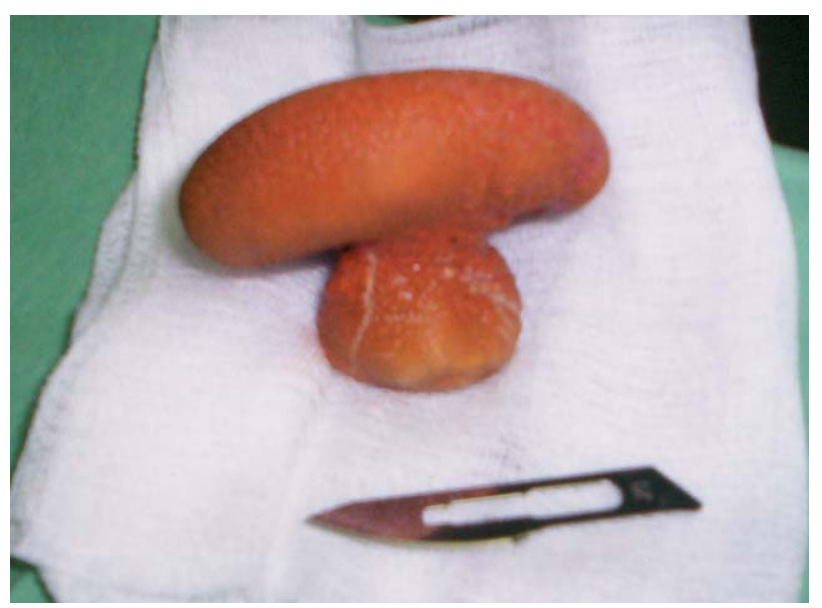
FIGURA 1 de hongo que había adquirido. En estos momentos el paciente sigue tratamiento profiláctico y se encuentra asintomático.

En las imágenes podemos comparar el tamaño de la litiasis con una hoja de bisturí del número 23.

Dr. J.P. Caballero Romeu

E-mail: caballero_jua@gva.es

(Trabajo recibido el 29 de noviembre 2005)

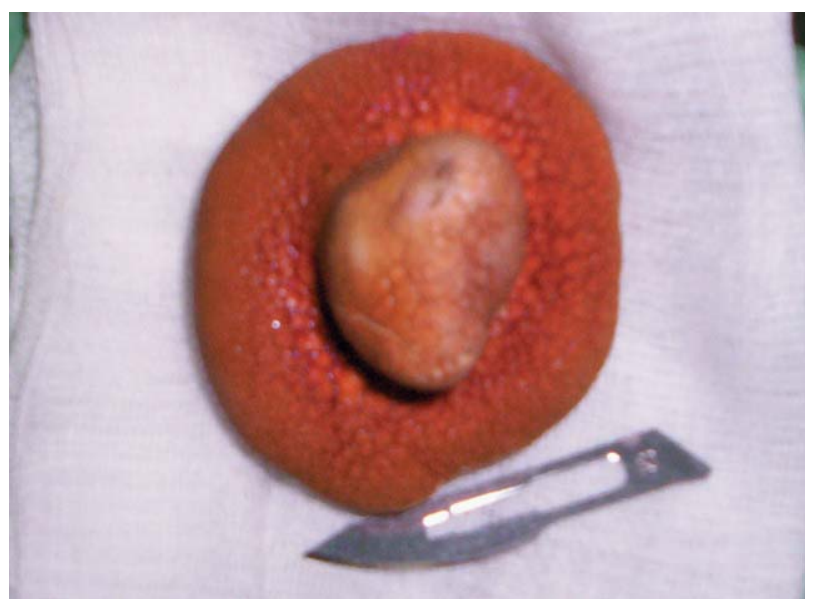

FIGURA 2 